\title{
Coalition Theory in Praxis: A Comparative Politics Simulation of the Cabinet Formation Process
}

\author{
Juliet Kaarbo, University of Kansas \\ Jeffrey S. Lantis, The College of Wooster
}

\begin{abstract}
While many role-playing simulations have been developed in the fields of international relations and American politics, few simulations exist for courses in comparative politics (Dodge 1983; Endersby and Webber 1995; Hensley 1993; Suransky 1983; Winham 1991). Yet many aspects of comparative politics seem particularly ripe for simulation. What simulations do best is provide a framework of rules that shape individual behavior (Walcott 1980). In this way, students can learn the effects of institutional design-a common theme in comparative politics-by experiencing these effects.

This article describes a role-playing simulation of coalition cabinet formation processes in Europe originally designed for an upper-level undergraduate course on Western European politics. Our project was designed to address a significant gap in the simulations literature with regard to comparative political analysis.
\end{abstract}

\section{Objectives}

This simulation was created with several educational objectives in mind. First, we sought to design a simulation to complement comparative politics instruction on Europe. The exercise was structured to illustrate very important dimensions of comparative political study such as electoral laws, the dynamics of coalition cabinet formation, and the sometimes conflicting roles of policy and power in the democratic process. Recognizing that basic instruction in comparative politics was a prerequisite, this exercise was originally designed to run in an advanced political science course entitled "The Politics of Western Europe" at the University of Kansas.

Second, the exercise was structured to provide an opportunity for experiential learning about the com- plexity of the coalition cabinet formation process in parliamentary democracies. Experiential learning is an excellent instructional tool that can generate real personal interest in a particular subject (McKeachie

\section{Experiential learning is an excellent instructional tool that can generate real personal interest in a particular subject.}

1986; Suransky 1983). We designed a simulation in which students are divided into groups of political parties in a fictitious country with a proportional representation electoral system. Students establish party platforms, design campaign strategies, monitor the final vote tallying, and try to form a coalition government. Participants try to "win" political support for their party platforms and representation in government. Even the "losing" parties get to participate in the formulation of an active opposition to the government and a shadow cabinet. As they work with other students to campaign for votes, form coalition governments, and establish coherent opposition programs, students gain important insights about the complexities of the political process generally, and the coalition cabinet formation process specifically. Experts on simulations point out that such experiences are beneficial for all participants (Gump and Woodworth 1987).

The exercise also has advantages because it can be closely linked with real-world events. Fortunately, parliamentary democracies around the world regularly hold elections that can be observed at a distance, and often the coalition cabinet formation process plays a very important role in those democratic transitions. During the first run of this exercise, for example, parliamentary elections were being conducted in the Federal Republic of Germany-thus providing the opportunity to relate developments to the classroom exercise. Recent developments in parliamentary democracies in Italy, Belgium, Turkey, and elsewhere have also provided illustrations of this process.

At its most basic level, the exercise introduces U.S. citizens to the dynamics of parliamentary systems quite different from the American model of democracy. In our experience, students who are U.S. citizens have great difficulty understanding the importance of the coalition cabinet formation process and its subtleties. One comparative scholar contends that American students often come into colleges with a parochial orientation and must be motivated to learn about comparative politics (Wilsford 1995). This exercise provides students with a great deal of insight into the process. Students are exposed to systems with more than two political parties, complicated histories, and interesting party constituencies. They learn about the importance of party organizations, the impact of proportional representation arrangements, political powersharing, the concepts of closure and connectivity in winning coalitions, and the fragility of democratic governments.

\section{Stages of the Coalition Exercise}

The coalition cabinet formation exercise was developed to fulfill these educational objectives and complement a lecture program on this theme. What follows is an overview of the stages of the exercise, the assignment structure, and rationale for specific aspects of the project. ${ }^{1}$ 


\section{Introduction and General Instructions}

The first stage of the exercise involved outlining the expectations for the students and supplying them with general instructions (Gump and Woodworth 1987). To receive credit for involvement (worth $10 \%$ of their final course grade), students were expected to be present and participate in all aspects of the exercise. Students were assigned roles as political leaders of a fictitious country, "The Kingdom of Occania," and were given a detailed description of the country. This included information on Oceania's geography, political history, demographics, and economy (see Table 1).2 Almost all of the information presented in the country description could be used by the students in writing election party platforms. A few entertaining facts about the country were also included.

\section{Party Formation}

Students were randomly divided into six party groups of roughly equal size in the next class session. The justification for the large number of parties was twofold. We wanted to encourage students to consider many alternatives and broader coalitions, and we were concerned about avoiding "social loafing" that is sometimes associated with large group projects. Thus, 30 students was an ideal class size for the simulation, creating party groups of about five students each.

The students joined other members of their parties and were encouraged to form a unique party identity in two ways. First, each party was given a particular constituency and important demographic information (see Table 2). The parties' background information resembled the major party groupings in West European party systems (i.e., center-right, center-left, liberals, greens, far right, and anti-party). This information was purposefully brief. We wanted to give students some unique identification, but allow room for creativity in the full construction of their party's goals.

Second, the parties were instructed to elect a party leader and

TABLE 1.

\section{Country Background Information}

The Kingdom of Oceania

Geography

Total Area: 250,000 sq. km.

Comparative Area: Slightly smaller than Montana.

Land Boundaries: 420 km border with Slobovia, $396 \mathrm{~km}$ border with Widgetland. Coastline: $2,100 \mathrm{~km}$.

Natural Resources: Oceania has few natural resources and is reliant on foreign oil, minerals, timber, coal, and iron ore. Oceania imports over $90 \%$ of its oil.

Land Use: $44 \%$ arable land; one of the continent's leading agricultural states.

Political History

Government: Oceania is a consolidated parliamentary democracy. Originally a monarchy, citizens established a constitutional democracy in 1842 . The democracy was restructured in 1919, and the monarch was allowed only to function as head of state. Oceania has a proportional representation electoral system, a bicameral parliament, and universal suffrage at age 18 .

Disputes: The boundaries of Oceania were formalized in the Treaty of Versailles after World War. I. However, Oceania and Slobovia both have historical claims to a region that contains an ethnic mix of $45 \%$ Slobs and $55 \%$ Oceanians, as well as valuable mineral deposits. The most recent dispute between the countries led to the "Brief War" in which Slobovia regained control of this province in 1981. Oceania suffered 4,000 casualties in the war, and tensions remain so long as both countries assert claims of control over this region. Oceania and Widgetland have had quiet relations, and the Widgets have remained neutral in these conficts.

Military Force: Army, Navy, and Air Forces; 500,000 troops. Defense expenditures have remained relatively constant (roughly $4 \%$ of GNP), but the troops patrolling the Oceania-Slobovia border region remain on high alert in the wake of the 1981 conflict.

\section{People}

Population: $54,000,000$. Oceania has a growth rate of $1 \%$ per annum, mostly due to an influx of immigrants.

Ethnic Divisions: primarily Oceanians, small Slob and Widget minorities; $45 \%$ Slob in disputed region.

Religion: 42\% Roman Catholic, 32\% Protestant, 9\% Muslim, 17\% unaffiliated or other.

Literacy and Education: $97 \%$ of adults; strong educational system, government controlled secondary and higher education institutions.

Labor Force: $40 \%$ industry; $15 \%$ agriculture.

\section{Economy}

Economic Overview: Oceania has an advanced market economy and is an exporter of manufactured products. It has an urbanized and skilled population that enjoys excellent living standards and comprehensive social welfare benefits, including a national health care system. Oceania is relatively poor in natural resources, but has developed a strong trade base. In recent years, manufacturing has accounted for about $31 \%$ of GNP. Oceania's growth rate was strong (over 4\% GNP per annum) until the worldwide recession of the 1980 s. Its current growth rate is $2.9 \%$, but economists in Oceania are making optimistic projections about future growth as inflation comes under control.

Employment: Oceania has a high unemployment rate, ranging around $9 \%$ per annum.

Exports: Manufactured goods including machine tools, chemicals, steel products; agricultural products, including wine.

Imports: Mostly raw materials including oil, some manufactured goods.

secretary. The leader received extra credit, but had to make the presentation of the party portfolio. The party secretary also received extra credit, but had to prepare final party documents. A Party Identification 
TABLE 2.

\section{Party Background Information}

Party \#1

Party \#1 is the oldest party organization in Oceania, with its origins in the popular movement against the monarchy in the early 1840 s. Your party has traditionally drawn its support from a wide range of the electorate including middle- and upper-class voters, both urban and rural. Your party includes a strong band of support from Roman Catholic voters and from the agricultural sector. Your party has been in power, but polls suggest a gradual loss of popular support.

\section{Party \#2}

You are leaders of the second-oldest party organization in Oceania. Your party was founded in the early 1900 s as part of a wave of social consciousness and developed a broad political base. Your party has traditionally drawn its support from urban working- and middle-class voters and trade union organizations. Your party has been in opposition for some time, and leaders are making efforts to capture new and old constituencies to return to power.

\section{Party \#3}

Party \#3 has been one of the most influential parties in Oceania for many years. Your party was founded in the 1950 s as an organization dedicated to balance and free thinking in the government. Your party has traditionally drawn its support from upper-class, urban, highly-educated citizens who see the party as a moderating influence on the two large, catch-all party organizations. Your party has participated in past governing coalitions.

\section{Party \#4}

Party \#4 is a relatively young party organization-founded in early 1981 by leaders who rejected the use of military force for national gain in the "Brief War." Your party draws its support from highly-educated, active citizens, particularly from the younger generation. Party leaders are hoping to maintain an active voice in the new parliament.

\section{Party \#5}

You are leaders of a party organization that had its roots in the popular movement against the monarchy in the early $1840 \mathrm{~s}$. In fact, your leadership splintered-off from the more mainstream conservative movement in the 1930 s. Your party traditionally draws its support from urban, disaffected voters. Your party is always in danger of losing its representation in parliament, but recent polls suggest renewed popularity.

\section{Party \#6}

Party \#6 only entered into the political fray this year as Oceania's newest party organization dedicated to challenging the status quo. Your party seems to draw its support from a diverse group of voters, many of whom consider your "alternative" as preferable to government policies. Your leaders are encouraged by growing support measured in the public opinion polls.

Sheet on which the students listed the party name, members, leader, and secretary was completed and turned in to the instructor at the end of this stage of the game.

\section{Party Platform Development}

Students were then given the opportunity to develop their party platform (portfolio). They were given most of a class period to work on this assignment and were encouraged to meet outside of class as well. Students were given a sheet of spe- cific instructions for the development of the platforms which included a requirement to cover three policy areas: economic issues, social concerns, and foreign affairs. Issues outside these three areas could also be included in the platform, but were not required. For each issue area, students were given a group of specific questions to stimulate their thinking. For example, on social issues, students were encouraged to consider how their party would change the education and health care systems and what would be their party's positions on abortion, nuclear energy, and environmental regulation.

Emphasis was placed on designing specific questions to define clearly party platforms and to facilitate party identification. Students were told to consider the characteristics of their country and the electorate. We stressed that students should come up with a platform that they believed in and one that responded directly to constituency concerns in order to increase their chance of electoral success. Students were also asked to name their own parties in relation to themes discussed in the course. Having been previously exposed to the historical background of basic party groupings-including Christian Democrats, Social Democrats, Communists, Liberals, Greens, and Radical Right parties-students were told to develop their party identification and name with direct reference to their constituency. This allowed students an opportunity to think about what different group labels mean and define their own organization based on these designs.

As part of the portfolio development process, students had to design some type of campaign advertisement for their party that would capture the major themes in their portfolios. Students were encouraged to be creative in the development of a campaign ad that would appear on the radio, on television, in a newspaper, or on a billboard. Radio ads could be presented on a taped audio recording, television ads could be presented on a video recording, or both could be presented "live" to the class. Newspaper and billboard ads could be presented on handouts or on a poster board in class.

\section{Presentation of Platforms and Advertisements}

Parties began in-class presentations of their policy positions in the third week of class. The parties were given a five minute limit for the presentation of their platform and main concerns. The campaign advertisement was also to be presented at this time. The time allowed for presentation was limited for two reasons: first, we were concerned that 
longer presentations would disrupt the normal course program; second, the shorter time limit would force students to focus on a central message. In fact, we believed that this shorter time allotment would give students a glimpse of real-world politics, where modern party leaders struggle over short sound bites and commercials. All party members were told they should be prepared to answer questions from the class. This forced full participation at this stage in the simulation. On average, students posed about three questions to the presenting partics, forcing the presenting party to clarify ambiguities and to highlight the differences between the parties.

The platform presentations were spread out over the following three weeks of the term in order to give students enough time to meet with each other, to react and modify their platforms to make them distinct, and to write up their presentation. One week after the first presentation, the second party presented its portfolio and advertisement. From that point on, a series of presentations was scheduled through the sixth week of the course. The ordering of presentations was also by design. The numbering of the parties corresponded to their relative degree of political support, with the higher numbered parties representing more narrow constituencies. In this way, they would be forced to modify their platforms in order to be distinct from earlier party platforms. Students were told specifically that their party platforms had to be sufficiently distinct from other parties for chances of electoral success. Thus, the higher numbered parties would be unable to latch onto the "mainstream" ideas presented by the first party leaders. In this context, we envisioned a kind of centrifugal force similar to the historical development of party systems in Europe.

\section{Election Results and \\ Cabinet Formation}

Once all six parties had given their presentations, students were ready for the announcement of the election results. The results were designed so that no single party had a majority (see Table 3 ). Two of the most mainstream parties had around $30 \%$ of the parliamentary seats, two parties were at $10-18 \%$, and two parties were under $9 \%$. A rough plan for vote outcome was established at the beginning of the exercise, but which party received the most seats in the larger, moderate, and small categories depended on how well each party had presented its platform and how well its platform was tailored to its constituency. Furthermore, the election results were designed so that the minimum winning coalition (the coalition with the bare minimum majority in parliament and the least number of parties) would bring parties together that had significant policy conflicts in their platforms. This distribution allowed for a number of alternative coalitions to be formed and made very clear the tradeoffs between the power-based minimum winning coalition and the policy-based connected coalition. The election results also included the percentage of popular votes each party received. With this, the results of an electoral law that rewards large parties and punishes small parties could be demonstrated to students concretely.

The remainder of this class period was allotted for the coalition cabinet formation process. Students were instructed to gather in party groups and reflect on the implications of the election results. They were given approximately five minutes to discuss which ministries would be most important to their parties and with which other parties they could reasonably share power. Then, they were allowed to enter into negotiations with other parties' representatives to consider forming a coalition and the balance of the distribution of ministries.

The largest party was told that it would have the first chance to form a cabinet and should try to find other parties that would join with it in a coalition. To form a government, the following conditions had to be met: 1) the coalition had to control $50 \%$ or more of the parliamentary seats; 2) each party had to agree to the distribution of ministries by signing a portfolio sheet (see Table 4); and 3) each party had to
TABLE 3. Election Results

\section{NEWS RELEASE}

The following news report was broadcast late last night on television:

"This just in ... the results of the national elections in Oceania are final. No single political party gained a majority of the vote. The results were:

\begin{tabular}{lcc} 
& $\begin{array}{c}\text { Percentage } \\
\text { of Popular } \\
\text { Vote }\end{array}$ & $\begin{array}{c}\text { Percentage } \\
\text { of Seats in } \\
\text { Parliament }\end{array}$ \\
\hline Party \#1 & $30 \%$ & $34 \%$ \\
Party \#2 & $21 \%$ & $23 \%$ \\
Party \#3 & $16 \%$ & $17 \%$ \\
Party \#4 & $14 \%$ & $13 \%$ \\
Party \#5 & $11 \%$ & $8 \%$ \\
Party \#6 & $8 \%$ & $5 \%$ \\
The voters have spoken. Party \\
leaders must now begin the difficult \\
process of forming a working \\
coalition government."
\end{tabular}

agree to a "viable" coalition policy statement covering three economic policy issues, three social policy issues, and three foreign policy issues. To be "viable," the coalition policy statement could not be in conflict with any of the parties' platform planks (the instructor and the rest of the class would judge whether such conflict existed). If the largest party could not form a cabinet within 30 minutes, they were told that the second largest party would be given an opportunity to form a different coalition.

The parameters for the coalition cabinet formation process were designed with several goals in mind. First, knowing that it was most likely that students would form a majority coalition cabinet, we emphasized the bargaining process and the possibility that a number of alternative coalitions might be formed. Second, this exercise introduced the twin goals of cabinet formation: power and policy. Getting into the government and obtaining a higher proportion of cabinet seats earned students extra credit points (more points for the 
most posts their party "won"). But to motivate policy considerations, the constraint of a viable coalition agreement was added. Thus, parties had to consider the compatibility of their own party's platform with the platforms of their prospective coalition partners. Moreover, the students could learn the art of papering-over differences by creating a broad, and vague, coalition agreement.

In addition, a time constraint was placed on the coalition cabinet formation efforts of the largest winning party in an effort to stimulate active bargaining. The possibility of the second largest party getting a chance to form its own coalition gave the largest party real consequences for failing to secure willing coalition partners, gave the small parties leverage with which to bargain by providing another opportunity, and gave the second largest party something to do during the negotiations over ministries and the coalition agreement (i.e., negotiate with the other parties in case the largest party failed). Once the second largest party concluded any negotiations, its members were told to form a shadow cabinet in case the current coalition negotiations are successful. They were given a few questions to discuss, such as: If the coalition falls, with which parties would you try to form a coalition? and What would your party change in its platform for the next election? Also during this time, students of the small parties that were not going to be part of the coalition cabinet were asked to be observers and reporters of the process.

\section{Discussion of Experiences}

Finally, one day of the course was set aside for a detailed discussion of the exercise and of comparative political theories of the process. Each stage of the game was discussed and students were encouraged to think critically about factors underlying their behavior and the implications for politics in Europe. For example, students were asked to reflect on the trade-offs in the development of party platforms between their convictions, getting elected, and recognizing dissenting factions. In terms of election results, the effects of electoral laws were discussed. Students were asked how the coalition cabinet formation would change if it were a pure proportional representation system or if a hurdle were introduced.

Most of the time in class discussions was allotted to issues of the coalition cabinet formation process. Coalition theory was introduced to the students, and the power prediction of a minimum winning coalition was compared to a policy prediction of high party preference agreement and to mixed predictions of connected winning coalitions. Other factors were also discussed including electoral strategies and the special role of "pivotal" and "pariah" parties in the process.

Discussion of these issues was facilitated by questions about the classroom exercise including: Which theory and factors best explain what happened in coalition formation? How were the ministries distributed in the coalition? Did the distribution reflect differences in the parties' policy platforms? Was the distribution disproportional to party parliamentary strengths? Would the coalition last?

\section{Assessment of the Simulation}

This simulation has consistently met the educational objectives of experiential learning and has provided students with a better understanding of the complexities of coalition cabinet formation. In both the class discussion and essay exam answers, students easily moved from their experience in the simulation to the more general analysis of coalition formation, electoral laws, party representation, and democratic stability. Student essays on actual countries often included reference to the game experience or to a counterfactual based on the simulation. In addition to the day set aside to discuss the game, subsequent lectures throughout the course frequently returned to the game to illustrate key issues. For example, when covering Scandinavia, students were asked to think about how the game would change if the majority requirement was abandoned and a minority cabinet was allowed to form. Thus, stu- dents learned about the complexity of the coalition cabinet formation process in parliamentary democracies (and other political processes inherent in such systems) that typically seem very distant and esoteric to U.S. citizens.

Student evaluations of the simulation have been very positive. A review of responses over the past three years shows that $81 \%$ agreed that the coalition formation exercise made the subject seam valuable, $84 \%$ agreed that it made the subject matter more interesting, and $72 \%$ agreed that it was effective overall. Slightly smaller majorities agreed that the exercise encouraged critical evaluation $(57 \%)$ and that the purpose of the exercise was clear $(69 \%)$. In open-ended questions asking what was most useful about the exercise. students mentioned extra benefits in addition to the objectives outlined above (e.g., building bargaining and communication skills, developing personal relationships with other class members, providing release from day-to-day lectures on comparative politics, and the "fun of competition").

Finally, students truly became engaged in the simulation and exhibited high levels of interest and creativity in their assignments. Students invented very creative names for their parties (e.g., the anti-government "Squash Party," the "Pic-Us Party"), and designed interesting campaign advertisements (e.g., the Squash Party smashed a squash as part of a "live" television ad, one party used the name of a state representative running for office and distributed the candidate's slick flyer as their own, the National Front party members dressed up in fatigues, and one party even created a homepage on the internet at http:/ falcon.cc.ukans.edu/ $\sim$ heather/ Oceania/). In addition, many gave enthusiastic speeches to deliver their platforms in class. Perhaps the most intellectually creative effort was one party's use of a text that student members were learning about in a political theory class (John Rawl's Theory of Justice) as the basis of their party platform. All of this suggested that students wore highly motivated to learn in this simulation by experiencing the process firsthand. 
TABLE 4.

\section{Coalition Portfolio Agreement}

DISTRIBUTION OF MINISTRIES IN THE REPUBLIC OF OCEANIA

$$
\text { PORTFOLIO }
$$

NAME

PARTY

\section{Prime Minister}

Minister for Foreign Affairs

Minister of Economics

Minister of Justice

Minister of Women \& Youth Issues

Minister of Defense

Minister of Education

\section{Concluding Remarks}

While this experience has been quite successful, student evaluations administered after the first run of the exercise also alerted us to problems that have been addressed in subsequent iterations. Some students, for example, found the coalition formation stage a bit chaotic-so the rules are now written down, discussed, and distributed to the class in advance of the scheduled formation. Students in the first run also believed that the extra credit awards were uneven since only the parties that made it into the coalition received bonus points. Now, the "losing" students are told (after the coalition formation stage is complete), that they can write a twopage summary of the formation process to receive extra credit as well. With these minor corrections, the simulation exercise has operated more smoothly and has been well received by students.

Several other issues and suggestions are worthy of further consideration. We have discussed dividing students into party groupings based on responses to personal opinion surveys gauging students' feelings on issues. One might divide students into parties according to similar ideologies and then give constituency bases to reinforce these clusters. This may help close the gaps that sometimes exist between the party background information and the platforms developed by the students. Second, we have considered whether it would have been valuable for students to make open predictions about which parties will be in the government and distribution of ministries immediately after the release of the mock election results. This would offer some demonstration of the reality of multiple possible outcomes. Third, we have discussed the utility of an exercise designed with multiple runs, which would allow the instructor to manipulate electoral laws and outcomes. A simple route would be to present very different election results on the second run, suggesting that a drastic change in the political climate produced surprising losses for the "mainstream parties." Another important lesson could be presented through the institution of minimum vote requirements for representation, or through the simple outlawing of fringe parties.

Teaching the comparative politics of government in Europe can be challenging. Lectures and readings on the different institutions and their effects may be difficult for students to become interested in or to understand. Coalition cabinet formationthe very essence of "who governs" in parliamentary systems-can seem esoteric to students only familiar with U.S. politics. Simulations like this one, which take advantage of showing how institutional design can affect behavior, can make education in comparative politics more fruitful and more fun-for both students and instructors.

\section{Notes}

1. Complete materials are available from the authors. Write: Professor Juliet Kaarbo, Department of Political Science, University of
Kansas, 504 Blake Hall, Lawrence, KS, 66045; or E-mail: kaarbo@a falcon.cc.ukans.edu.

2. Although we opted for a fictitious country ("Oceania") so that students would not simply copy patterns of any particular, actual country, this cxercise could be adapted to any number of scenarios-whether actual or mythical.

\section{References}

Dodge, Dorothy R. 1983. "Domestic Politics Games and Simulations: An Evaluation." In The Guide to Simulations/Games for Education and Training, ed. Robert Horn and Anne Cleaves. Beverly Hills, CA: Sage.

Endersby, James W., and David J. Webber. 1995. "Iron Triangle Simulation: A RolePlaying Game for Undergraduates in Congress, Interest Groups, and Public Policy Classes." PS: Political Science \& Politics 28(3): $520-23$.

Gump, W. Robert, and James R. Woodworth. 1987. Atlantis: Role Playing Simulations for the Study of American Politics. Chicago: Nelson-Hall.

Honsley, Thomas R. 1993. "Come to the Edge: Role Playing Activities in a Constitutional Law Class." PS: Political Science \& Politics 26(1): 64-8.

McKeachie, Wilbert J. 1986. Teaching Tips: A Guidebook for the Beginning College Teacher. Lexington, MA: D C Health and Company.

Suransky, Leonard. 1983. "International Relations Games and Simulations." In The Guide to Simulations/Games for Education and Training, ed. Robert Horn and Anne Cleaves. Beverly Hills, CA: Sage.

Walcott, Charles. 1980. Simple Simulations 2. Washington, DC: American Political Science Association.

Wilsford, David. 1995. "Getting Students to Think (Comparatively): Teaching the Introductory Course in the 1990s." PS: Political Science \& Politics 28(2): 221-26.

Winham, Gilbert R. 1991. "Simulation for Teaching and Analysis." In Intemational Negotiation, ed. Victor Kremenyuk. San Francisco: Jossey-Bass Publishers.

\begin{abstract}
About the Authors
Juliet Kaarbo is assistant professor of political science at the University of Kansas. Her research focuses on foreign policy decision making in parliamentary democracies and has recently appeared in International Studies Quarterly and Cooperation and Conflict.

Jeffrey $\mathbf{S}$. Lantis is assistant professor of political science and chair of the international relations program at The College of Wooster. He is author of the forthcoming book, Domestic Constraints and the Breakdown of International Agreements (Praeger Publishers, 1998).
\end{abstract}

